\title{
Evaluation of Corrosion Resistance in 3.5\% NaCl Solution of Hybrid Coatings Obtained from Plastics Materials
}

\author{
ALINA CRINA MURESAN, DANIELA LAURA BURUIANA*, GABRIEL BOGDAN CARP, \\ SORIN BERBECE, CONSTANTIN TRUS*
}

Dunarea de Jos University of Galati, 47 Domneasca Str., 800008, Galati, Romania

\begin{abstract}
In this work, the corrosion resistance of hybrid coatings obtained from plastic materials was evaluated and compared with the corrosion resistance of Zn coatings. Zinc and hybrid coatings were obtained by electrodeposition from zinc sulphate electrolyte. For obtained hybrid coatings it was used as disperse phase two type of plastic materials: phenol-formaldehyde resin and epoxy resin. Polarization was used to measure the corrosion rate and behaviour of zinc and hybrid coatings in 3.5\% $\mathrm{NaCl}$ solution. Tafel curves show that the including particles of plastic materials in zinc matrix disturbs the cathodic reactions and reduces anodic reaction leading to decrease of corrosion current and increase the corrosion resistance of hybrid coatings obtained at the same electrodeposition parameters as zinc coatings. Smallest values of corrosion rate were evaluated for hybrid coatings obtained with phenolformaldehyde resin as disperse phase that indicates a good corrosion resistance in $3.5 \% \mathrm{NaCl}$ solution.
\end{abstract}

Keywords: plastic materials, zinc, electrodeposition, corrosion resistance

\section{Introduction}

Hybrid materials are mixtures of two or more components whose properties complement each other, resulting in a material with properties superior to that specific to each component [1]. The advantages of these new materials can be stated as follows: corrosion resistance, breaking strength, wear resistance, high-temperature resistance, surface hardness, dimensional stability, vibration damping capacity, environmental resistance, thermal conductivity or thermal insulation, conductivity electricity, wetting capacity, relatively low price etc. [2-21].

Corrosion is a material degradation caused by the chemical reaction with other materials and/or the environment [22]. There are a limited number of papers concerning hybrid coatings with plastic materials as disperse phase. Such coatings present good anticorrosion properties. Zinc coatings have good corrosion resistance in most neutral media. When exposed to the atmosphere, zinc provides good corrosion protection for steel, but in rural and marine environments in conditions of moisture and chloride pollution decreases the corrosion efficiency of zinc coatings. For alkaline and marine environments can be used cadmium coatings for o good corrosion protection of steel. Zinc is preferred as coatings for steels used in water or the marine environment because it is non-toxic such as cadmium and can be used in applications requiring welding. The lifespan of zinc coatings is dependent on the thickness of the layer and less on the method of application, and the electrolyte sulfate electrodeposits are much better than those of cyanide electrolytes [23]. The excellent performance of zinc coatings lies in the fact that they form dense, adherent films of corrosion products and thus the corrosion rate is 10 or 100 times lower than that of ferrous materials, the corrosion rate depending on the environment. For these reasons is necessary to improve the corrosion behaviour of pure zinc coatings using different disperse phase included in the zinc matrix. Phenol formaldehyde resin and epoxy resin are used usually as polymeric coatings because act as a barrier to protect steel from different corrosion environments and are widely used for industrial applications [24-26].

For obtaining zinc hybrid coatings are used different methods: hot-dip galvanizing, thermal diffusion or cementation, metallization or spraying, contact process (without external power source) and electrodeposition [27]. Among the processes to produce hybrid coatings, the electrodeposition has

*email:dana.negoita@gmail.com; dilconstantin@yahoo.com 
further demonstrated that a smoother surface, better bonding between disperse phase and metal, a higher microhardness and good corrosion behavior can be achieved. More than that electrodeposition gives uniform deposits and deposition rate, the thickness of the layers can be controlled by electrodeposition parameters and is an attractive method owing to low-cost equipment and raw materials [28].

The aim of this work was to evaluate the behaviour and corrosion resistance in $3.5 \% \mathrm{NaCl}$ solution of zinc and hybrid coatings with disperse phase plastic materials obtained by electrodeposition in a zinc sulphate electrolyte. As disperse phase for electrodeposition it was used two types of plastic materials: phenol-formaldehyde resin and epoxy resin. The corrosion resistance of hybrid coatings and pure zinc coatings in $3.5 \% \mathrm{NaCl}$ solution was estimated using electrochemical methods (open circuit potential and potentiodynamic polarization method). Corrosion resistance was evaluated using the values of corrosion current, polarization resistance and rate of corrosion for hybrid coatings versus the values of same parameters for pure zinc coatings. The values of parameters mention before indicate o good corrosion resistance for hybrid coatings versus corrosion resistance of zinc coatings in tested medium.

\section{Materials and methods}

\subsection{Preparation of pure zinc coatings and hybrid coatings}

As substrate for electrodeposition, it was used DC04 carbon steel with the following chemical composition and mechanical properties: C 0.04\%; Mn 0.20\%; Si 0.02\%; P 0.018\%; S 0.012 \%; Al $0.060 \%$, yield strength $140-210 \mathrm{MPa}$ at $20^{\circ} \mathrm{C}$; tensile strength $270-350 \mathrm{MPa}$ at $20^{\circ} \mathrm{C}$ and elongation $\mathrm{A} 80$ $38 \%$ at $20^{\circ} \mathrm{C}$. Typical applications for this type of carbon steel are to be found in the automotive industry, the domestic appliance sector, metal furniture, drums, radiators, fans, small welded tubes and small profiles.

The sulphate electrolytes used for electrodeposition of pure zinc coatings and hybrid coatings are: $1.078 \mathrm{~mol} / \mathrm{L} \mathrm{ZnSO}_{4} \cdot 7 \mathrm{H}_{2} \mathrm{O} ; 0.232 \mathrm{~mol} / \mathrm{L} \mathrm{Na}_{2} \mathrm{SO}_{4} \cdot 10 \mathrm{H}_{2} \mathrm{O} ; 0.045 \mathrm{~mol} / \mathrm{L} \mathrm{Al}_{2}\left(\mathrm{SO}_{4}\right)_{3} \cdot 18 \mathrm{H}_{2} \mathrm{O}$. To improve the characteristics of the electrolyte solution the conductivity was increased by using sodium sulphate. The acidity of electrolyte was maintained and stabilized at a value of $p \mathrm{H}=3.8$ with aluminium sulphate. The parameters for electrodeposition used for pure zinc and hybrid coatings was: current density of 30 $\mathrm{mA} / \mathrm{cm}^{2}, 40 \mathrm{~mA} / \mathrm{cm}^{2}$ and $50 \mathrm{~mA} / \mathrm{cm}^{2}$; electrodeposition time of $30 \mathrm{~min}$ for $40 \mathrm{~mA} / \mathrm{cm}^{2}$ and $60 \mathrm{~min}$ for $30 \mathrm{~mA} / \mathrm{cm}^{2}$ and $50 \mathrm{~mA} / \mathrm{cm}^{2}$. The disperse phase added in the electrolyte solution for obtaining hybrid coatings was in the quantity of $25 \mathrm{~g} / \mathrm{L}$ plastic materials particles in zinc sulphate electrolyte solution with a mean diameter size of particles $6-10 \mu \mathrm{m}$. The properties of phenol-formaldehyde resin used as disperse phase are molecular weight $3392-3816 \mathrm{~g} / \mathrm{mol}$; melting point $70-80^{\circ} \mathrm{C}$; viscosity at $120^{\circ} \mathrm{C} 35-45 \mathrm{~Pa}^{\cdot} \mathrm{s}$, free phenol $<1 \%$, water content $<0.5 \%$. The phenol-formaldehyde resin is not esterified. The properties of epoxy resin used as disperse phase are weight 900-1200 g/mol; density $1.18-1.25 \mathrm{~g} / \mathrm{cm}^{3}$; melting point $64-76{ }^{\circ} \mathrm{C}$; epoxy index $0.185-0.220$ equivalents in $100 \mathrm{~g}$ resin $100 \%$; free volatile compounds $<1 \%$. Homogeneity of the system was maintained by stirring with a rate of $800 \mathrm{rpm}$. All electrodeposition was carried out at room temperature. Surfactants or additives were not used in the zinc sulphate electrolyte because they could react with plastic material particles.

The symbols for tested samples are presented in Table 1.

Table 1. Symbols of samples used for corrosion tests

\begin{tabular}{|c|c|}
\hline Samples & Electrodeposition parameters \\
\hline $\mathrm{Zn} 1$ & current density: $30 \mathrm{~mA} / \mathrm{cm}^{2}$, time $60 \mathrm{~min}$ \\
\hline $\mathrm{Zn} 2$ & current density: $40 \mathrm{~mA} / \mathrm{cm}^{2}$, time $30 \mathrm{~min}$ \\
\hline $\mathrm{Zn} 3$ & current density: $50 \mathrm{~mA} / \mathrm{cm}^{2}$, time $60 \mathrm{~min}$ \\
\hline $\mathrm{PF} / \mathrm{Zn} 1$ & $\begin{array}{c}\text { current density: } 30 \mathrm{~mA} / \mathrm{cm}^{2} \text {, time } 60 \mathrm{~min}, 25 \mathrm{~g} / \mathrm{L} \text { phenol-formaldehyde resin, mean diameter size } \\
\text { of particles } 6-10 \mu \mathrm{m}\end{array}$ \\
\hline $\mathrm{PF} / \mathrm{Zn} 2$ & $\begin{array}{c}\text { current density: } 40 \mathrm{~mA} / \mathrm{cm}^{2}, \text { time } 30 \mathrm{~min}, 25 \mathrm{~g} / \mathrm{L} \text { phenol-formaldehyde resin, mean diameter size } \\
\text { of particles } 6-10 \mu \mathrm{m}\end{array}$ \\
\hline $\mathrm{PF} / \mathrm{Zn} 3$ & current density: $50 \mathrm{~mA} / \mathrm{cm}^{2}$, time $60 \mathrm{~min}, 25 \mathrm{~g} / \mathrm{L}$ phenol-formaldehyde resin, mean diameter size \\
\hline
\end{tabular}




\begin{tabular}{|c|c|}
\hline & of particles $6-10 \mu \mathrm{m}$ \\
\hline Ep/Zn1 & $\begin{array}{c}\text { current density: } 30 \mathrm{~mA} / \mathrm{cm}^{2} \text {, time } 60 \mathrm{~min}, 25 \mathrm{~g} / \mathrm{L} \text { epoxy resin, } \\
\text { mean diameter size of particles } 6-10 \mu \mathrm{m}\end{array}$ \\
\hline Ep/Zn2 & $\begin{array}{c}\text { current density: } 40 \mathrm{~mA} / \mathrm{cm}^{2} \text {, time } 30 \mathrm{~min}, 25 \mathrm{~g} / \mathrm{L} \text { epoxy resin, } \\
\text { mean diameter size of particles } 6-10 \mu \mathrm{m}\end{array}$ \\
\hline Ep/Zn3 & $\begin{array}{c}\text { current density: } 50 \mathrm{~mA} / \mathrm{cm}^{2} \text {, time } 60 \mathrm{~min}, 25 \mathrm{~g} / \mathrm{L} \text { epoxy resin, } \\
\text { mean diameter size of particles } 6-10 \mu \mathrm{m}\end{array}$ \\
\hline
\end{tabular}

The parameters that varied were current density and time for electrodeposition. The other parameters $(p \mathrm{H}$, stirring rate, temperature, quantity and dimension of plastic materials particles added in the electrolyte) were maintained at same for all samples.

\subsection{Characterization of the coatings}

\subsubsection{Thickness of the coatings}

The thickness of coatings was evaluated using an optical microscope via sample cross-section.

\subsubsection{Corrosion tests by electrochemical methods}

To evaluate the open circuit potential and potentiodynamic polarization parameters (corrosion potential, anodic and cathodic Tafel slopes, corrosion current density, polarization resistance and corrosion rate) it was used a Voltalab PGP 201 and the values were recording and evaluate using VoltaMaster 4 software. For a good reproducibility of obtained data, each type of sample was tested three times.

Electrochemical measurements were performed in a three-electrode open cell with tested samples (pure zinc coatings, phenol-formaldehyde/zinc hybrid coatings and epoxy resin/zinc hybrid coatings) as working electrode (W.E.), a platinum plate as a counter electrode (C.E.) and a saturated calomel electrode (SCE) as a reference electrode ( $\mathrm{SCE}=+241 \mathrm{mV} / \mathrm{NHE})$. Monitoring of open circuit potential was for $60 \mathrm{~min}$ till the values of corrosion potential were stable vs. saturated calomel electrode potential used. For polarization curves, it was used initial potential (I.P.) $-1.5 \mathrm{~V}\left(\mathrm{Hg} / \mathrm{Hg}_{2} \mathrm{Cl}_{2}\right.$ ), final potential (F.P.) $-0.8 \mathrm{~V}\left(\mathrm{Hg} / \mathrm{Hg}_{2} \mathrm{Cl}_{2}\right)$ and a scan rate of $0.5 \mathrm{mV} / \mathrm{s}$. The Tafel parameters were recorded after $30 \mathrm{~min}$ of immersion of the tested samples in $3.5 \% \mathrm{NaCl}$ solution.

\section{Results and discussions}

\subsection{Thickness of the coatings}

The thickness of the coatings obtained in cross-section using optical microscopy are presented in Figure $1(\mathrm{a}, \mathrm{b}$ and $\mathrm{c})$.

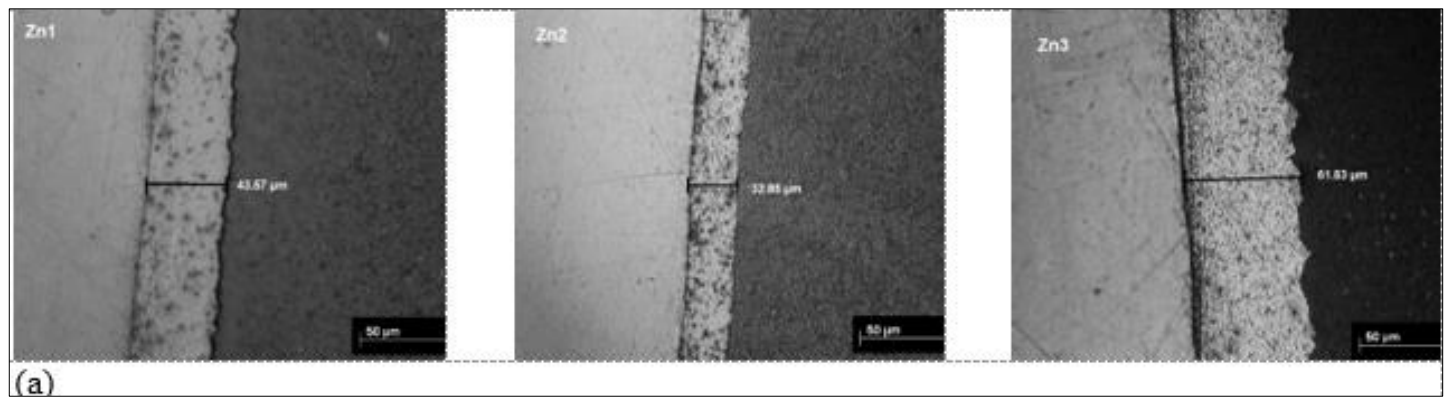



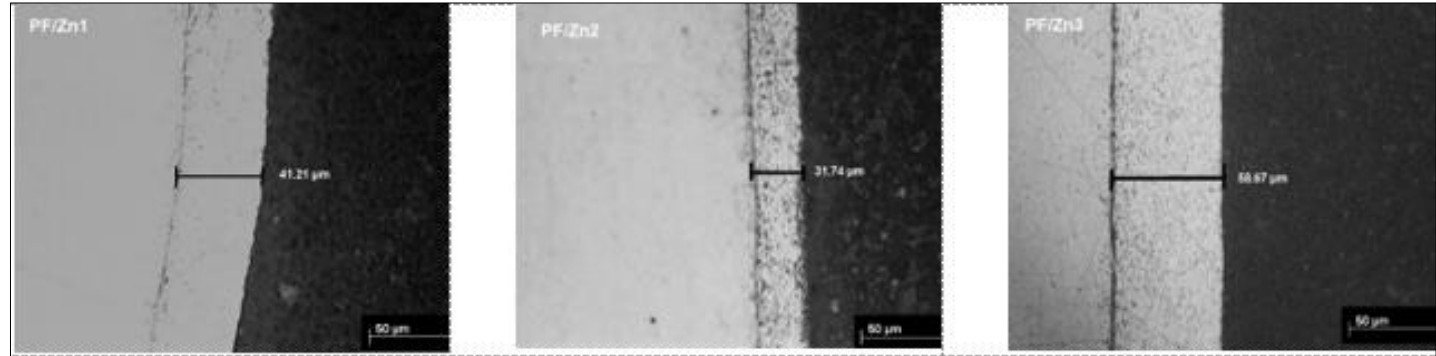

(b)
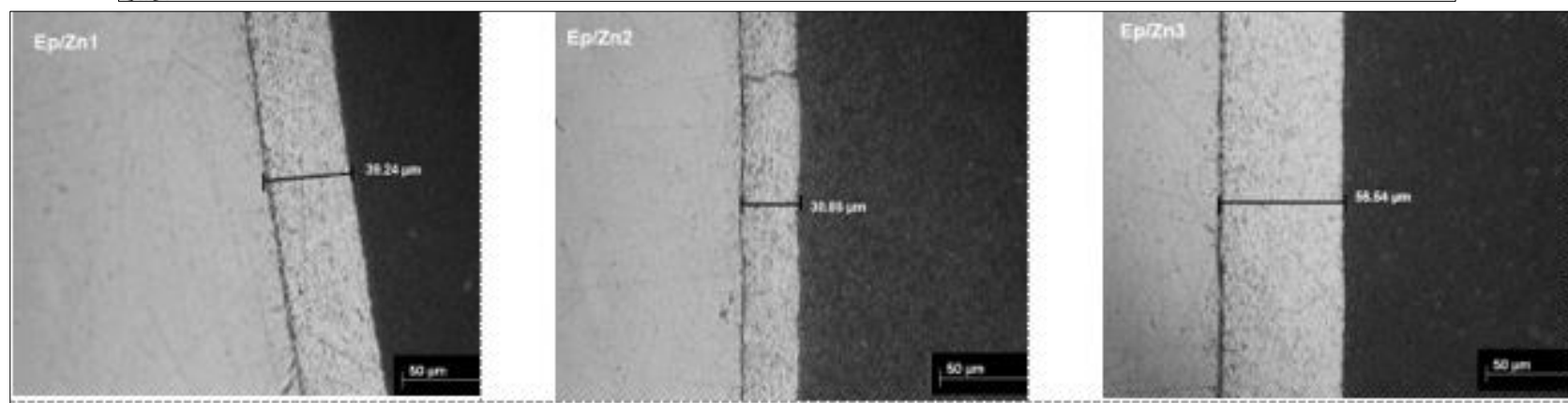

(c)

Figure 1. Cross - section images obtaining with optical microscopy showing the thickness of (a) zinc coatings, (b) phenol formaldehyde resin/zinc hybrid coatings and (c) epoxy resin/zinc hybrid coatings (X 500)

The values of layers thickness presented in Table 2 indicate an increase of layers thickness with an increase of current density and time for electrodeposition. The highest values were obtained for coatings obtained of $50 \mathrm{~mA} / \mathrm{cm}^{2}$ with electrodeposition time of $60 \mathrm{~min}$ and the smallest values were obtained for samples obtained of $40 \mathrm{~mA} / \mathrm{cm}^{2}$ with electrodeposition time of $30 \mathrm{~min}$. Also, it could be observed that the smallest values of thickness layers it was obtained for coatings with plastic materials, probably the plastic materials used as disperse phase have an inhibition effect of zinc crystals growth and a catalytic effect in increasing nucleation sites, considering that the trends and influence of the polymers will be the same that in previous studies $[29,30]$.

The thickness of the coatings is an important parameter because the life cycle of the materials depends on their thickness. The function of corrosion rate it possible to obtained optimal layers thickness of a coating using optimum electrodeposition parameters.

Table 2. The thickness of pure zinc coatings and hybrid coatings

\begin{tabular}{|c|c|}
\hline Type of samples & Thickness of the coatings layers, $\boldsymbol{\mu m}$ \\
\hline $\mathrm{Zn} 1$ & 43.57 \\
\hline $\mathrm{Zn} 2$ & 32.85 \\
\hline $\mathrm{Zn} 3$ & 61.83 \\
\hline $\mathrm{PF} / \mathrm{Zn} 1$ & 41.21 \\
\hline $\mathrm{PF} / \mathrm{Zn} 2$ & 31.74 \\
\hline $\mathrm{PF} / \mathrm{Zn} 3$ & 58.67 \\
\hline $\mathrm{Ep} / \mathrm{Zn} 1$ & 39.24 \\
\hline $\mathrm{Ep} / \mathrm{Zn} 2$ & 30.85 \\
\hline $\mathrm{Ep} / \mathrm{Zn} 3$ & 56.54 \\
\hline
\end{tabular}

\subsection{Electrochemical corrosion measurements}

Open circuit potential (OCP) tests give information about the stability of the tested samples. By using OCP is measured only the resting potential measured between reference and a working electrode. The evolution of the potential during time is due to the reactions at the hybrid material-solution interface. OCP is a thermodynamic parameter which tells about the thermodynamic tendency of metallic materials to participate in the electrochemical corrosion reactions with the corrosion environments. 
The results obtained from the monitoring of OCP during $60 \mathrm{~min}$ for all tested samples are presented in Figures 2 ( $a, b$ and $c)$.

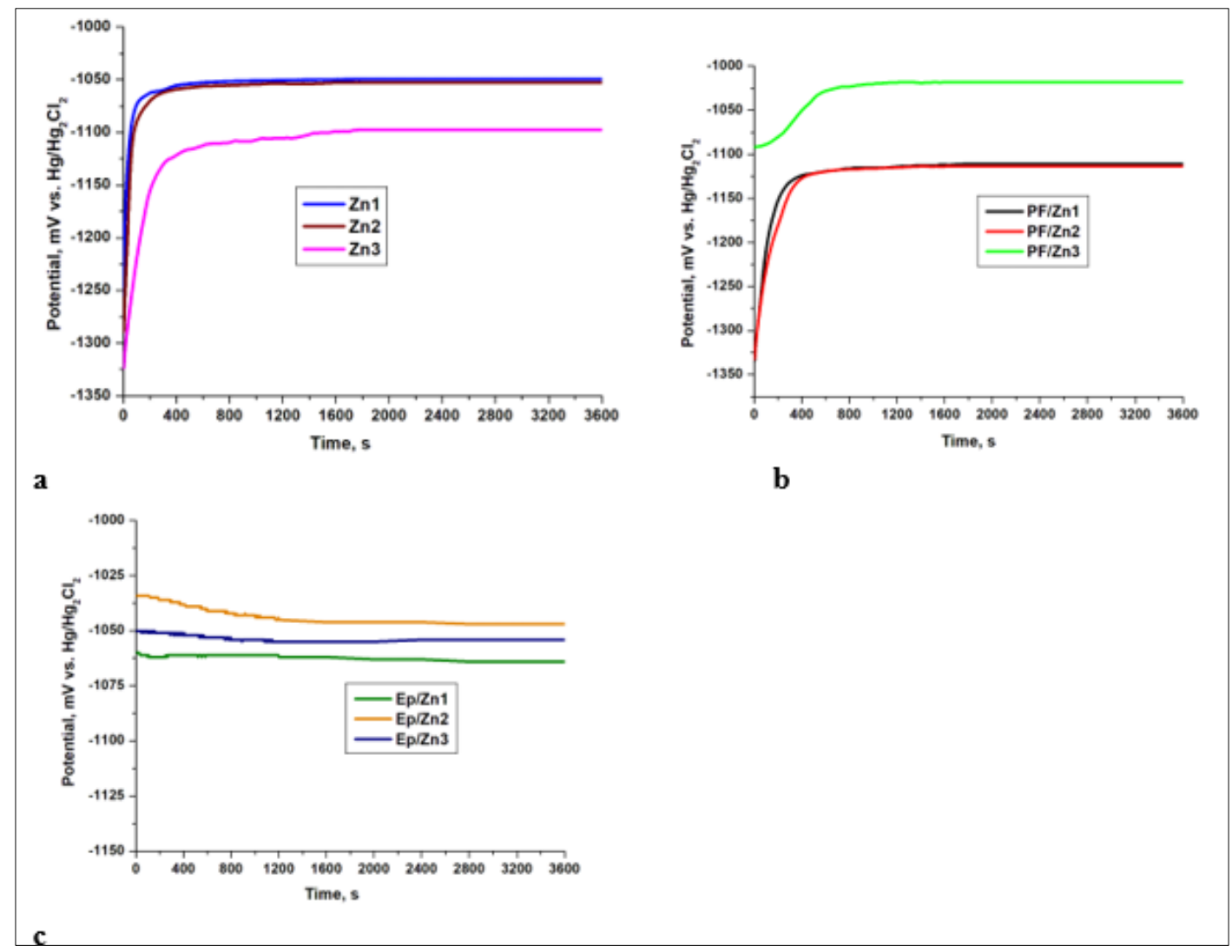

Figure 2. Evolution of open circuit potential measurements for (a) zinc coatings,

(b) phenol-formaldehyde/zinc hybrid coatings and (c) epoxy resin/zinc hybrid Coatings in $3.5 \% \mathrm{NaCl}$ solution

From the values of the OCP for all tested samples it could be observed that the variation of potential in time is very slow. Samples are stabilized in approximatively $10 \mathrm{~min}$ after immersion in $3.5 \% \mathrm{NaCl}$ solution. Epoxy resin/zinc hybrid coatings samples are more stable in tested solution because the OCP has the smallest variation in time. For samples tested the values of the OCP are in the range of -1018 $\mathrm{mV}$ and $-1113 \mathrm{mV}$.

The results of open circuit potential recording for $\mathrm{Zn} 3$ and $\mathrm{PF} / \mathrm{Zn} 3$ showed that pure zinc coatings sample presented a more active potential than the PF/Zn3. That fact indicate that the surface of pure zinc coatings is more susceptible to corrosion comparing with surfaces of hybrid coatings.

The Tafel curves obtained after 30 min of immersion in $3.5 \% \mathrm{NaCl}$ solution in the potential range from $-1.5 \mathrm{~V}$ to $-0.8 \mathrm{~V}$ are presented in Figures 3 ( $\mathrm{a}, \mathrm{b}$ and $\mathrm{c}$ ). Quantitative information on corrosion currents and corrosion potentials can be extracted from the slope of the curves, using the Stern-Geary equation [31]:

$$
\mathrm{j}_{\text {corr }}=\frac{\mathrm{B}}{\mathrm{R}_{\mathrm{p}}}
$$

While the B parameter (Stern-Geary parameter) was evaluated using the equation:

$$
\mathrm{B}=\frac{\mathrm{b}_{\mathrm{a}} \cdot\left|\mathrm{b}_{\mathrm{c}}\right|}{2.303 \cdot\left(\mathrm{b}_{\mathrm{a}}+\left|\mathrm{b}_{\mathrm{c}}\right|\right)}
$$


$\mathrm{j}_{\text {corr }}$ means the corrosion current density; $\mathrm{R}_{\mathrm{p}}$ means polarization resistance and $\mathrm{b}_{\mathrm{a}}, \mathrm{b}_{\mathrm{c}}$ means anodic and cathodic Tafel slopes.

By using Tafel extrapolation can be calculated different parameters (corrosion potential, Tafel slopes, corrosion current density, polarization resistance, corrosion rate) that indicate corrosion behaviour of samples tested. These parameters are presented in Table 3.

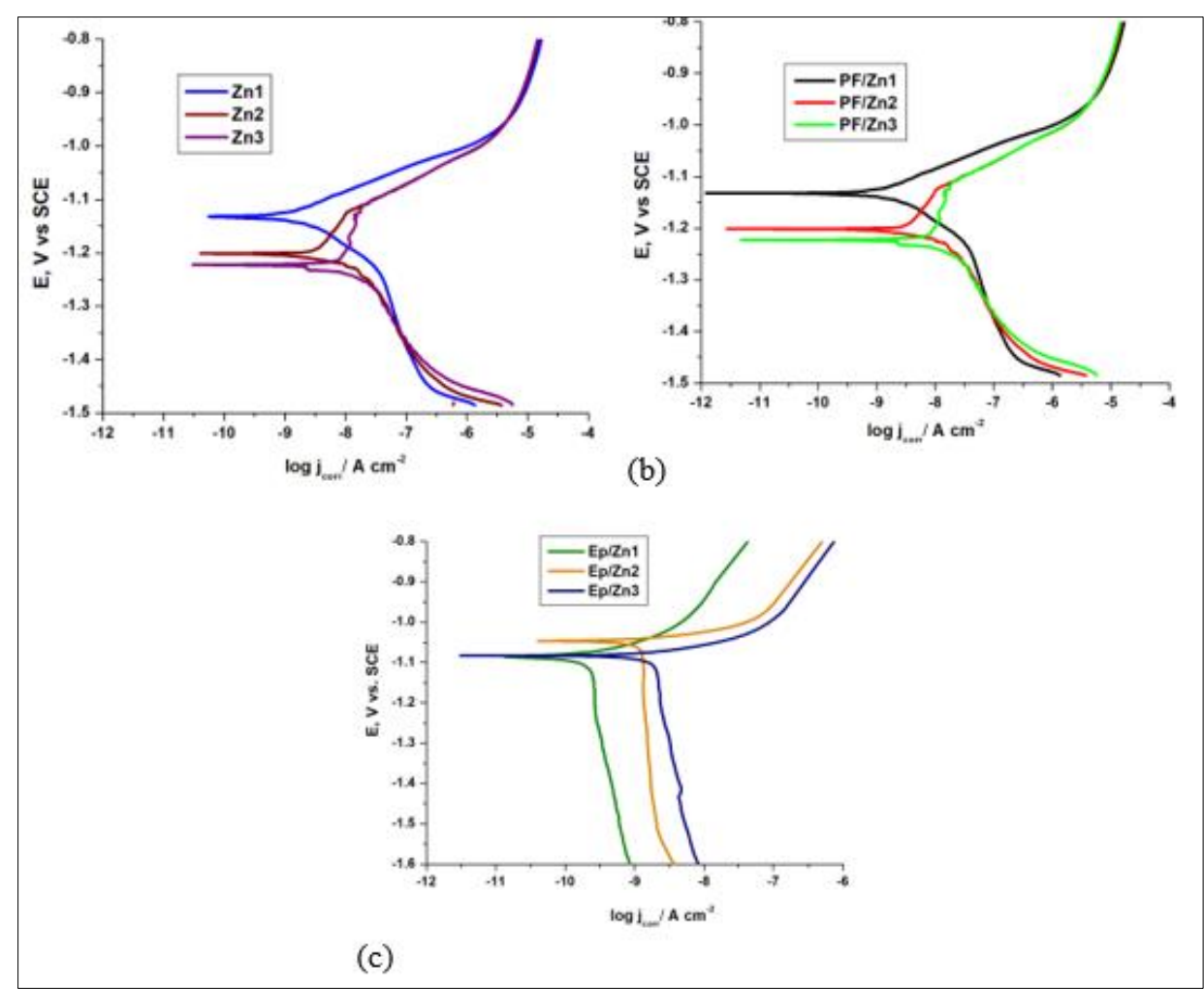

Figure 3. Tafel curves of (a) zinc coatings, (b) phenol-formaldehyde resin/zinc hybrid coatings and (c) epoxy resin/zinc hybrid coatings in $3.5 \% \mathrm{NaCl}$ solution after 30 min from immersion time (logarithmical)

Table 3. Tafel parameters of zinc coatings and hybrid coatings with plastic materials evaluated from polarization curves obtained in $3.5 \% \mathrm{NaCl}$ solution after $30 \mathrm{~min}$ of immersion

\begin{tabular}{|c|c|c|c|c|c|}
\hline $\begin{array}{c}\text { Type of } \\
\text { samples }\end{array}$ & $\begin{array}{c}E_{\text {corr }}(\text { vs SCE) } \\
\text { V }\end{array}$ & $\beta_{\mathrm{a}}, \mathrm{V} /$ decade & $\begin{array}{c}\left|\beta_{\mathrm{c}}\right|, \\
\text { V/decade }\end{array}$ & $\begin{array}{c}\text { jeorr }{ }^{\cdot 10^{-6}}, \\
\mathrm{~A} / \mathrm{cm}^{2} \\
\end{array}$ & $\begin{array}{c}\mathbf{R}_{\mathrm{p}}, \\
\Omega \cdot \mathrm{cm}^{2}\end{array}$ \\
\hline $\mathrm{Zn} 1$ & -1.133 & 26.54 & 22.17 & 160.16 & 32.75 \\
\hline $\mathrm{Zn} 2$ & -1.204 & 43.18 & 27.14 & 91.80 & 78.82 \\
\hline $\mathrm{Zn} 3$ & -1.222 & 33.45 & 28.40 & 53.51 & 124.63 \\
\hline $\mathrm{PF} / \mathrm{Zn} 1$ & -1.132 & 25.75 & 24.59 & 10.07 & 542.37 \\
\hline $\mathrm{PF} / \mathrm{Zn} 2$ & -1.201 & 31.60 & 37.10 & 20.08 & 369.02 \\
\hline PF/Zn3 & -1.222 & 47.64 & 26.97 & 20.51 & 364.58 \\
\hline $\mathrm{Ep} / \mathrm{Zn} 1$ & -1.085 & 26.30 & 48.00 & 46.25 & 159.51 \\
\hline $\mathrm{Ep} / \mathrm{Zn} 2$ & -1.046 & 21.10 & 161.80 & 76.36 & 106.14 \\
\hline $\mathrm{Ep} / \mathrm{Zn} 3$ & -1.082 & 24.30 & 71.20 & 52.60 & 149.55 \\
\hline
\end{tabular}

From the data presented in Table 3, it could be concluded that by adding phenol-formaldehyde resin and epoxy resin in electrolyte solution was obtained hybrid coatings with a better corrosion resistance than zinc coating in $3.5 \% \mathrm{NaCl}$ solution. A higher value of polarization resistance and a smaller value of corrosion current density indicate a good corrosion resistance of materials. For polarization resistance it was calculated values between $32.75-124.63 \Omega \cdot \mathrm{cm}^{2}$ for zinc coatings, $364.58-542.37 \Omega \cdot \mathrm{cm}^{2}$ for phenol-formaldehyde resin/zinc hybrid coatings and 106.14-159.51 $\Omega \cdot \mathrm{cm}^{2}$ for epoxy resin/zinc hybrid coatings. These values indicate an improvement of corrosion resistance of zinc coatings in $3.5 \% \mathrm{NaCl}$ solution by adding in electrolyte solution plastic materials particles. 
Using the values of corrosion current density and equation (3) it was evaluating the corrosion rate of tested samples (Figure 4).

$$
C R(\mathrm{~mm} / \text { year })=\frac{K \cdot j_{\text {corr }} \cdot E W}{d}
$$

where $\mathrm{k}$ is a conversion factor equal with 3272 , $\mathrm{j}_{\text {corr }}$ is corrosion current density calculated from SternGeary equation $\left(\mathrm{A} / \mathrm{cm}^{2}\right)$; EW represents the equivalent weight of corroding species $(\mathrm{g})$, while $d$ is density of the corroding species $\left(\mathrm{g} / \mathrm{cm}^{3}\right)$. For hybrid coatings the equivalent weight values are not influence too much by the polymers because these materials (phenol formaldehyde resin and epoxy resin) were used as disperse phase and zinc used as matrix is majority in hybrid coatings. In order to evaluate the corrosion rate of hybrid coatings it was used the equivalent weight of zinc. Because the density of plastic materials is very tiny comparing with the density of zinc for evaluate corrosion rate it was used the density of zinc metal (zinc density $=7.133 \mathrm{~g} / \mathrm{cm}^{3}$, density of phenol formaldehyde resin $=1.16-1.21 \mathrm{~g} / \mathrm{cm}^{3}$ and density of epoxy resin $\left.=1.18-1.25 \mathrm{~g} / \mathrm{cm}^{3}\right)$.

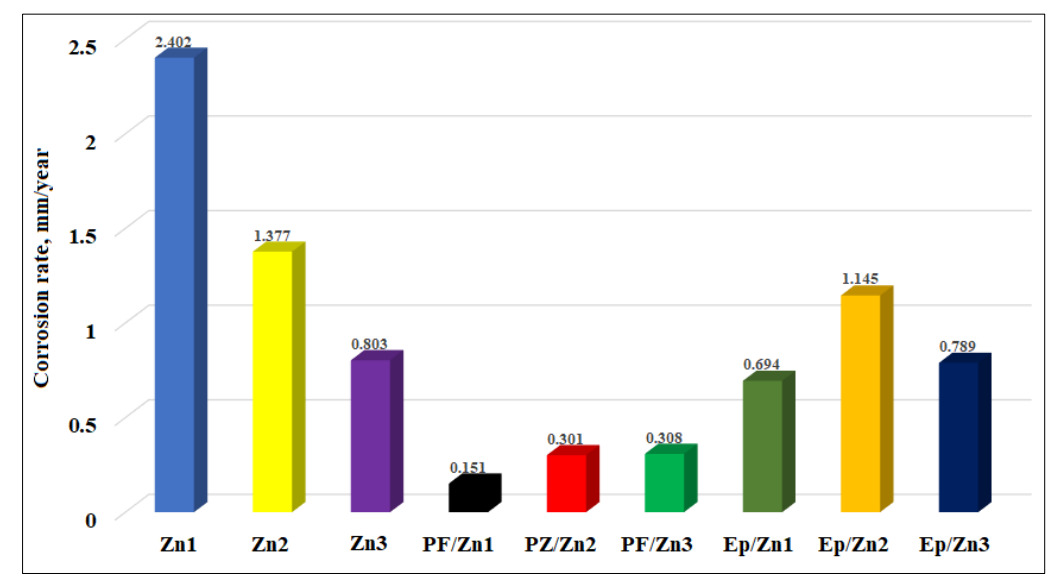

Figure 4. The corrosion rate of tested samples

Comparing the values of corrosion rate obtained for tested samples could be concluded that phenolformaldehyde/zinc hybrid coatings have very good corrosion resistance in $3.5 \% \mathrm{NaCl}$ with smaller values of corrosion rate between $0.151-0.308 \mathrm{~mm} / \mathrm{year}$. Good corrosion resistance was obtained for epoxy resin/zinc hybrid coatings with corrosion rate values between $0.694-1.145 \mathrm{~mm} / \mathrm{year}$. The corrosion rate for zinc coatings has the highest values between $0.803-2.402 \mathrm{~mm} /$ year that indicate the smallest corrosion resistance of zinc in $3.5 \% \mathrm{NaCl}$ comparing with corrosion resistance of hybrid coatings.

It was remark only one exception for zinc coatings obtained at $50 \mathrm{~mA} / \mathrm{cm}^{2}$, electrodeposition time $60 \mathrm{~min}$ where the value of corrosion rate $(0.803 \mathrm{~mm} / \mathrm{year})$ was smaller than epoxy resin/zinc coatings obtained at $40 \mathrm{~mA} / \mathrm{cm}^{2}$, electrodeposition time $30 \mathrm{~min}$ (1.145 mm/year).

From corrosion rate data obtained for hybrid coatings can be concluded that these types of coatings could be used for industrial purposes to minimise the losses of zinc generated from corrosion in an aggressive environment.

\section{Conclusions}

Corrosion of materials is an important concern for the materials scientist. This natural phenomenon causes substantial financial losses in different industries and requires extensive efforts to limit its impact.

The research presented shows that it could be possible to obtain hybrid coatings, by adding plastic materials particles in electrolyte solution, with very good corrosion resistance in an aggressive environment using electrodeposition, a method with low cost and easy to used.

From the values of layers, thickness obtained it was observed an increase of layers thickness with increases current density and time for electrodeposition. 
The values of the open circuit potential for all tested samples shows that the variation of potential in time is very slow, that indicates good stability of the tested materials in $3.5 \% \mathrm{NaCl}$.

By adding plastic materials particles in sulphate electrolyte solution, it was obtained hybrid coatings with a better corrosion resistance than zinc coatings in $3.5 \% \mathrm{NaCl}$ solution.

Hybrid coatings obtained with plastic materials could be used for industrial purposes, method of obtaining is easy with low cost and the hybrid coatings obtained present an improvement of corrosion rate comparing with zinc coatings.

\section{References}

1. ZWEBEN, C., Mechanical Engineers' Handbook, Chapter 10. Composite Materials, Fourth Edition, edited by Myer Kutz, Publisher John Wiley \& Sons, Inc., 2015, 1-37.

2. FLINN, R.A., TROJAN, P.K., Engineering Materials and Their Applications, 4th edition, Boston, Houghton Mifflin Company, 1990.

3. PRAVEEN, B.M., VENKATESHA, V.T., Electrodeposition and properties of Zn-nanosized $\mathrm{TiO}_{2}$ composite coatings, Appl. Surf. Sci., 254 (8), 2008, 2418-2424.

4. MISKOVIC-STANKOVIC, V.B., ZOTONIC, J.B., KACAREVIC-POPOVIC, Z., MAKSIMOVIC, M.D., Corrosion behaviour of epoxy coatings electrodeposited on steel electrochemically modified by Zn-Ni alloy, Electrochim. Acta, 44 (24), 1999, 4269-4277.

5.VELEVA, L., CHIN, J., DEL AMO, B, Corrosion electrochemical behavior of epoxy anticorrosive paints based on zinc molybdenum phosphate and zinc oxide, Prog Org. Coat., 36, 1999, 211-216.

6.MESSLE, R R.W. Jr., Joining Composite Materials and Structures: Some Thought-Provoking Possibilities, J. Thermoplas. Compos. Mater., 17 (1), 2004,51-75.

7.SANCAKOGLU, O., CULHA, O., TOPARLI, M., AGADAY, B., CELIK, E, Co-deposited Znsubmicron sized $\mathrm{Al}_{2} \mathrm{O}_{3}$ composite coatings: Production, characterization and micromechanical properties, Mater. Des., 32 (7), 2011, 4054-4061.

8.KACZMAR, J.W., PIETRZAK, K., WLOSINSKI, W., The Production and Application of Metal Matrix Composites, J. Maters. Process. Technol,106 (1-3), 2000, 58-67.

9. YE, H.Z, LIU, X.Y., Review of recent studies in magnesium matrix composites, J. Mater. Sci., 39 (20), 2004, 6153-6171.

10. KOLEVA, D., ZHANG, X., PETROV, P., BOSHKOV, N., VAN BREUGEL, K., DE WIT, J.H.W., MOL, J.M.C., TSVETKOVA, N., Zinc Composite Layers, Incorporating Polymeric Nano-aggregates: Surface Analysis and Electrochemical Behavior, ECS Transactions, 11 (11), 2008, 27-35

11. LING, H.J., MAI, Y.J., LI, S.L., ZHANG, L.Y., LIU C.S., JIE X.H., Microstructure and improved tribological performance of graphite/copper-zinc composite coatings fabricated by low pressure cold spraying, Surf. Coat Tech., 364, 2019, 256-264.

12. IQBAL, N., IQBAL, S., IQBAL, T., BAKHSHESHI-RAD, H. R., ALSAKKAF, A., KAMIL, A., ABDUL KADIR, M.R., IDRIS M.H., RAGHAV, H.B., Zinc-doped hydroxyapatite-zeolite /polycaprolactone composites coating on magnesium substrate for enhancing in-vitro corrosion and antibacterial performance, Trans. Nonferrous Met. Soc. China, 30, 2020, 123-133.

13. REKHA, M.Y., SRIVASTAVA, C., Microstructure and corrosion properties of zinc-graphene oxide composite coatings, Corros. Sci., 152, 2019, 234-248.

14. XIAO, F., QIAN, C., GUO, M., WANG, J., YAN, X., LI, H., YUE, L., Anticorrosive durability of zinc-based waterborne coatings enhanced by highly dispersed and conductive polyaniline/graphene oxide composite, Prog. Org. Coat., 125, 2018, 79-88.

15. LI, W., FAN, Z., LI, X., JIANG, YAN, F., ZHANG, Z., WANG X., Improved anti-corrosion performance of epoxy zinc rich coating on rusted steel surface with aluminum triphosphate as rust converter, Prog. Org. Coat, , 135, 2019, 483-489.

16. XUE, M.S., LI, W., WANG, F.J., Effect of surface $\mathrm{ZnO}$ coatings on oxidation and thermal stability of zinc films, Superlattice Microst., 48, 2010, 213-220. 
17. JEON, H., LEE, I., OH, Y., Changes in thermal conductivity and thermal shock resistance of YSZ$\mathrm{SiO} 2$ suspension plasma spray coatings according to various raw material particle sizes, Ceram. Int., 47, 2021, 3671-3679.

18.LIA, C.Y., FANA, X.L., CUIA, L.Y., ZENGA, R.C., Corrosion resistance and electrical conductivity of a nano ATO-doped MAO/methyltrimethoxysilane composite coating on magnesium alloy AZ31, Corros. Sci., 168, 2020, 108570.

19.GATZENA, M., RADELA, T., THOMYA, C., VOLLERTSEN, F., Wetting and solidification characteristics of aluminium on zinc coated steel in laser welding and brazing, J. Mater. Process. Technol., 238, 2016, 352-360.

20.KAMBUROVAA, K., BOSHKOVAA, N., BOSHKOVA, N., ATANASSOVAB, G., RADEVAA, T., Hybrid zinc coatings for corrosion protection of steel using polyelectrolyte nanocontainers loaded with benzotriazole, Colloids Surf. A, 559, 2018, 243-250.

21.KAMBUROVAA, K, BOSHKOVAA, N., TABAKOVAB, N., BOSHKOVA, N., RADEVAA, TS., Application of polymeric modified polyaniline-silica particles for improved corrosion resistance of hybrid zinc coatings, Colloids Surf. A, 592, 2020, 124546.

22. JONES, D., Principles and Prevention of Corrosion, Macmillan, New York, NY, USA, 1992.

23. GAMBURG, Y.D., ZANGARI, G., Theory and Practice of Metal Electrodeposition, Publisher Springer-Verlag New York, 2011.

24. PAZDEROVA, M., BRADAC, M., VALAS, M., Qualitative analysis of composite Zn-PTFE coatings, MM Sci. J., November 2010, 208-209.

25. KAMBUROVA, K., BOSHKOVA, N., TABAKOVA, N., BOSHKOV, N., RADEVA, Ts., Application of polymeric modified polyaniline-silica particles for improved corrosion resistance of hybrid zinc coatings, Colloids Surf. A Physicochem. Eng. Asp., 592, 2020, article 124546.

26. VASILAKOPOULOS, D., BOUROUSHIAN, M., Electrochemical codeposition of PMMA particles with zinc, Surf. Coat. Technol., 205 (1), 2010, 110-117.

27. American Galvanizers Association, Zinc coatings, 6881 S Holly Circle, Suite 108 Centennial, Colorado 80112, www.galvanizeit.org

28. MUSIANI, M., Electrodeposition of composites: an expanding subject in electrochemical materials science, Electrochim. Acta, 45, (20), 2000, 3397-3402.

29. CIUBOTARIU, A.C., BENEA, L., PONTHIAUX, P., Corrosion resistance of zinc-resin hybrid coatings obtained by electro-codeposition, Arab. J. Chem., 12 (8), 2019, 4427-4437.

30. CIUBOTARIU, A.C., BENEA, L., MITOŞERIU, O., PONTHIAUX, P., WENGER, F., Influence of particles size on the morphology and corrosion behaviour of phenol - formaldehyde/Zn composite coatings obtained by electrodeposition, J. Optoelectron. Adv. Mater., 11 (6), 2009, 892 - 897.

31.VELEZ, W., MATTA, F., ZIEHL, P., Electrochemical characterization of early corrosion in prestressed concrete exposed to salt water, Mater. Struct., 49, 2016, 507-520

Manuscript received: 22.09 .2020 